\title{
PELATIHAN PEMANFAATAN LIMBAH KELAPA (LIDI) MENJADI KERAJINAN TANGAN dI NAGARI IV KOTO MUDIK KECAMATAN BATANG KAPAS KABUPATEN PESISIR SELATAN
}

\author{
I Ketut Budaraga ${ }^{1}$ Syafrudin $^{2}$, Gusriati $^{3}$, Wawan Sumarno $^{4}$
}

\begin{abstract}
Industri kreatif adalah salah satu usaha untuk membantu peningkatan pendapatan masyarajat. Buah Kelapa adalah satu jenis tumbuhan dari suku aren-arenan atau Arecaceae dan anggota tunggal dalam marga Cocos. Kelapa dimanfaatkan hampir semua bagiannya oleh manusia sehingga dianggap sebagai tumbuhan serba guna, khususnya bagi masyarakat pesisir. Kelapa juga sebutan Pohon Kehidupan. Selama ini dimanfaatkan buahnya sedangkan daun dan kulitnya dibuang. Untuk meningkatkan nilai tambah kelapa, maka dilakukan pelatihan. Tujuan pengabdian ini adalah meningkatkan pengetahuan masyarakat dalam pemanfaatan limbah kelapa (lidi) menjadi kerajinan tangan sehingga ada peningkatan penghasilan. Metode yang dipergunakan berupa ceramah dan praktek. Kegiatan diadakan pada tanggal 1 Desember 2018 bertempat di Kantor Walinagari IV Koto Mudik. Jumlah peserta pelatihan 30 orang orang. Hasil dari kegiatan pelatihan ini, peserta pelatihan sudah mampu membuat kerajinan tangan berupa piring tempat makan, tempat buah.
\end{abstract}

Kata kunci : Pemanfaatan, lidi kelapa, kerajinan tangan

\begin{abstract}
The creative industry is one of the efforts to help increase community income. Coconut fruit is a type of plant from aren-arenan or Arecaceae and a single member in the Cocos family. Coconut is used by almost all parts of it by humans so it is considered a versatile plant, especially for coastal communities. Coconut is also called the Tree of Life. So far, the fruit is used while the leaves and skin are removed. To increase the added value of coconut, training is conducted. The purpose of this service is to increase public knowledge in utilizing coconut waste (sticks) to be handicrafts so that there is an increase in income. The method used is in the form of lectures and practices. The activity was held on December 1, 2018 at the Walinagari IV Koto Mudik Office. The number of trainees is 30 people. As a result of this training activity, the trainees were able to make handicrafts in the form of a place to eat dishes, fruit places.
\end{abstract}

Keywords: Utilization, coconut sticks, handicrafts

\section{PENDAHULUAN}

Dalam menghadapi era perdagangan bebas, sangat dibutuhkan peningkatan persaingan pasar guna meningkatkan perekonomian yang lebih seimbang serta peningkatan pemanfaatan sumber daya alam agar lebih berguna untuk masyarakat. Salah satu sumber daya alam yang bisa kita manfaatkan adalah buah kelapa. Salah satu limbah buah kelapa yang bisa dimanfaatkan serat serabut kelapa. Serat sabut kelapa, atau dalam perdagangan dunia dikenal sebagai Coco Fiber, Coir Fiber, Coir Yarn, Coir Mats, dan Rugs merupakan produksi hasil pengolahan sabut kelapa. Secara tradisional serat sabut kelapa hanya dimanfaatkan untuk bahan pembuat sapu, keset, tali dan alat rumah

\footnotetext{
${ }^{1)}$ Staf Pengajar Program Studi Teknologi Hasil Pertanian Faperta Universitas Ekasakti, email :ketut_budaraga@yahoo.com; budaraga1968@gmail.com

${ }^{2)}$ Pengrajin dan pengusaha olahan lidi kelapa dari Kota Pariaman

${ }^{3,4)}$ Staf Pengajar Program Studi Agribinis Faperta Universitas Ekasakti.
} 
tangga lain. Perkembangan teknologi, sifat kimia-fisika serat, dan kesadaran konsumen untuk kembali kebahan alami, membuat serat sabut kelapa dimanfaatkan menjadi bahan baku industri karpet, jok dan dashboard kendaraan, kasur, bantal, dan hardboard. Serat sabut kelapa juga dimanfaatkan untuk pengendalian erosi. Serat sabut kelapa diproses untuk dijadikan Coir Fiber Sheet yang digunakan untuk lapisan kursi mobil, Spring Bed dan lain-lain (Tuasikal et.al, 2015)

Nagari IV Koto Mudik salah satu nagari yang ada di Kecamatan Batang Kapas yang merupakan daerah bagian utara dari Kabupaten Pesisir Selatan. Secara Geografis terletak pada 100 derajat 34,16 detik - 100 derajat 53,62 detik Bujur Timur dan 1 derajat 15,00 detik - 1 derajat 38,00 detik Lintang Selatan dengan luas daerah 395,07 km2 atau 6,24 \% dari Luas Kabupaten Pesisir Selatan. Jika dilihat dari segi penggunaan lahan, kecamatan ini masih diliputi oleh kawasan hutan. Luas kawasan hutan $68,11 \%$ dari luas daerah. Lahan untuk budidaya pertanian $21,45 \%$, pemukiman $1,28 \%$ dan 9,16\% semak belukar. Ada 3 sungai yang mengaliri kecamatan ini yaitu sungai Batang Kapas, sungai Tuik dan Sungai Jalamu. Khusus lahan usaha tani padi sawah ada 1.842 ha $(5,13 \%)$. Rata-rata hari hujan 11,42 hari dan curah hujan $347,75 \mathrm{~mm}$. Jika dilihat dari segi fisik maka di kecamatan ini punya potensi untuk mengembangan kerajinan dari lidi kelapa (Anonim, 2016).

Usaha kerajinan dari lidi kelapa merupakan usaha dengan memanfaatkan limbah kelapa yang selama ini terbuang. Bahan baku kelapa tersedia disekitar petani, kadang-kadang ditanam disekitar rumah. Dari segi fisik, sosial, ekonomi dan keadaan lingkungan sangatlah tepat dilakukan kegiatan pemberdayaan masyarakat melalui peningkatan produktifitas kelapa dengan memanfaatkan limbah kelapa (lidi) menjadi produk kerajinan seperti piring tempat makan, tempat buah dan lain-lain. . Dengan kegiatan pemanfaatan limbah kelapa menjadi produk kerajinan ini dapat dapat meningkatkan pendapatan rumah tangga dan sebagai langkah konservasi tanaman kelapa (Wikipidia,2015).

Masyarakat petani di Nagari IV Koto Mudik sangat menginginkan teknologi tepat guna yang dapat meningkatkan pendapatan keluarga. Kegiatan pembuatan kerajinan ini merupakan kegiatan sampingan yang bisa dikerjakan ketika pekerjaan rumah selesai. Untuk itu kegiatan ini sangat cocok buat ibu-ibu rumah tangga dan anak-anak sekolah. Adanya tambahan penghasilan nantinya akan sangat membantu mengingat biaya kebutuhan hidup semakin mahal dan dan daya beli petani yang menurun. Kendala tersebut menyebabkan usahatani yang dilakukan kurang menguntungkan petani, sehingga perlu ada usaha sampingan.

Dalam rangka untuk peningkatan pendapatan keluarga dalam rangka menunjang ketahanan pangan rumah tangga, sangat diperlukan peningkatan produksi dan efisiensi biaya dalam melakukan usaha seperti membuat kerajinan dari limbah kelapa. Dengan adaanya kegiatan sampingan ini diharapkan penerimaaan rumah tangga petani bisa meningkat dan lebih lanjut tentu pendapatan yang diterima oleh petani menjadi lebih baik, sehingga mereka dapat memenhui kebutuhannya, baik kebutuhan usahatani maupun kebutuhan rumah tangga lainnya. Salah satu kegiatan yang dapat dilakukan adalah melalui pemanfaatan limbah kelapa (lidi) menjadi produk kerajinan dengan memanfaatkan bahan-bahan limbah dari kelapa seperti lidi yang banyak tersedia disekitar mereka. Kegiatan ini akan dapat meningkatkan pendapatan, menekan biaya pengeluaran rumah tangga. Metode ini juga menekankan kepada peningkatan pelestarian tanaman kelapa sebagai sumber tambahahan penghasilan kepada petani. Melalui kegiatan pelatihan ini akan dapat meningkatkan pendapatan sekaligus nilai tambah kelapa menjadi meningkat.

Melalui metode ini diharapkan kelestarian lingkungan dapat tetap terjaga dengan baik. Ketahanan pangan ditingkat rumah tangga merupakan suatu sistem yang terintegrasi dan berkelanjutan antara ketersediaan, distribusi dan konsumsi pangan. Sistem ini menjamin adanya ketersediaan pangan dengan distribusi yang merata dan sesuai dengan besarnya kebutuhan rumah tangga. Ketersediaan pangan rumah tangga petani sangat tergantung dari hasil produksi pertaniannya dan hasil penjualan 
kerajinan. Petani miskin dengan lahan yang sempit sering mengalami kekurangan pangan, ditambah lagi faktor lain seperti bencana dan keadaan iklim yang kurang menguntungkan memperparah keadaan petani. Melalui kegiatan pelatihan pemanfaatan limbah kelapa (lidi) menjadi produk kerajinan diharapkan dapat meningkatkan pendapatan rumah tangga petani.

Dari hasil survei ke lokasi yang dijadikan lokasi penyuluhan dan pelatihan ternyata petani sebenarnya ingin meningkatkan pendapatan melalui melalui tambahan disamping dari usaha tani padi yang memang sudah menjadi mata pencarian utama mereka. Petani merespon positif terhadap teknologi tepat guna yang akan diterapkan. Adapun teknologinya yaitu pembuatan kerajinan dari lidi menjadi produk-produk yang berguna seperti menjadi iring, temat buah dan lain.lain. Untuk merubah kebiasaan lama yang sudah turun-temurun dalam usaha memang perlu adanya pendampingan yang intensif. Untuk menjamin keberlangsungan kegiatan pembuatan kerajinan lidi, dari pihak perguruan tinggi juga sudah menyiakan mitra yang akan membeli produk masyarakat

Limbah kelapa (lidi) tersedia cukup banyak karena rata-masyarakat mempunyai tanaman kelapa disekitar rumah. Selama ini limbah kelapa berupa daun belum termanfaatkan secara optimal, padahal jika digunakan menjadi produk kerajinan bisa menambah pendapatan, apabila pengerjaan pembuatan produk kerajinan dikerjakan ketika waktu luang. Berdasarkan hasil diskusi dengan kelompok sasaran diketahui bahwa masyarakat sangat menginginkan adanya pendampingan dalam pembuatan kerajinan lidi yang sekaligus bisa menyiapkan pasar. Tujuan yang ingin dicapai dalam kegiatan ini adalah : 1. Meningkatkan pengetahuan dan keterampilan kelompok masyarakat dalam membuat kerajinan lidi menjadi produk yang bermanfaat. yang nantinya bisa memberikan keuntungan yang lebih baik, 2. Kelompok Masyarakat mampu membuat produk kerajinan lidi menjadi produk yang bermanfaat, 3 . Kelompok masyarakat mampu meningkatan manajemen usaha dan menganalisis usaha yang mereka lakukan, 4. Melestarikan lingkungan melalui pelestarian tanaman kelapa, 5. Meningkatkan pendapatan masyarakat malalui pembuatan produk kerajinan, 6 . Mengembalikan dan mengembangkan produk lokal dan menghilangkan ketergantungan masyarakat terhadap terhadap produk luar,7. Menunjang terciptanya industri kreatif dimasyarakat.

Sasaran yang ingin dicapai dalam kegiatan ini adalah : 1 . Terwujudnya kelompok masyarakat yang memanfaatkan IPTEKS dan menerapkan manajemen usaha dalam usaha pembuatan produk kerajinan serta memiliki keberlanjutan dan secara simultan dicontoh oleh kelompok masyarakat lain, 2. Tersedianya produk kerajinan lidi diproduksi sendiri oleh kelompok masyarakat, 3. Tersedianya model pemberdayaan masyarakat dalam membantu mewujudkan industri kreatif.

\section{METODE PELAKSANAAN}

\subsection{Khalayak Sasaran Strategis}

Kegiatan ini diikuti oleh para anggota masyarakat, seperti ibu-ibu PKK, ibu-ibu Kelompok Wanita Tani dan remaja putri serta wakil -wakil masyarakat di Kanagarian IV Koto Mudik, Kecamatan Batang Kapas, Kabupaten Pesisir Selatan, sebanyak 30 orang

\subsection{Tahapan Pelaksanaan}

\subsubsection{Persiapan}

Untuk pelaksanaan kegiatan penyuluhan pelatihan dimulai dari persiapan meliputi : Langkah 1. Rekruitmen masyarakat peserta pelatihan, Langkah 2. Sosialisasi ke masyarakat pengguna program,

Langkah 3. Persiapan perlengkapan. Perlengkapan yang akan disiapkan adalah surat izin ke instansi terkait, perlengkapan masyarakat seperti lidi, pewarna, dan lain-lain. 


\subsubsection{Pelaksanaan.}

Kegiatan dilaksanakan pada bulan Desember 2018 di kantor Walinagari IV Koto Kecamatan Batang Kapas Kabupaten Pesisir Selatan dengan program: sosialisasi dan pelatihan serta demonstrasi pembuatan produk kerajinan dari lidi. Selanjutnya praktek langsung di tempat pelatihan. Metode yang digunakan dalam pelatihan ini adalah: (1). Metode ceramah: untuk menjelaskan tentang materi . mulai pengenalan bahan baku lidi yang baik. Pada materi ini diperkenalkan perihal lidi yang dianggap bagus untuk dibuat kerajinan seperti lidi tidak terlalu tua, tidak cacat, (2) Demontrasi pengenalan motif-motif kerajinan, Pada pengenalan motif-motif kerajinan diperkenalkan bahan pewarna lidi, bentuk-bentuk kerajinan seperti piring tempat makan, piring tempat buah termasuk kaca cermin dengan bingkai lidi kelapa (3) Praktek pembuatan kerajinan. Pada praktek diminta kepada masing-masing peserta mampu membuat satu piring makan/peserta, (4). Metode komando: untuk memberi aba-aba dalam pelaksanaan pelatihan, (5). Metode resiprokal: metode dengan ciri ada pelaku dan pengamatnya, sehingga peserta bisa saling melakukan dan saling menilai terhadap temannya

Metode Pendekatan yang digunakan adalah: (1) Partisipasi kelampok masyarakat dalam perencanaan kegiatan, pelaksanaan, pengawasan dalam pemanfaatan limbah kelapa (lidi) menjadi produk kerajinan, (2) Kemandirian kelompok masyarakat petani dalam keberlanjutan kegiatan, (3). Kemitraan, antara petani dengan Perguruan Tinggi, dan instansi terkait.

Lembaga Mitra. Lembaga yang menjadi mitra pada kegiatan penyuluhan dan pelatihan ini adalah Walinagari IV Koto Mudik Kecamatan Batang Kapas Kabupaten Pesisir Selatan. Profil kelompok sasaran. Selama ini mata pencaharian masyarakat adalah melakukan budidaya padi secara konvensional. Ketika melakukan kegiatan pertanian masih banyak waktu luang yang belum dimanfaatkan. Pekerjaan di bidang pertanian seperti budidaya padi tidak membutuhkan waktu secara terus menerus. Adanya kegiatan pembuatan kerajinan dari lidi akan bisa lebih mengefektifkan waktu yang terbuang.

Target dan Luaran kegiatan. Target : (1). Peningkatan pendapatan minimal 10\%, (2). Kelompok dapat memproduksi sendiri produk kerajinan lidi, memakai sendiri dan bisa memasarkan, (3). Mendapatkan mitra untuk pemasaran berikutnya supaya terjadi kesinambungan program, (4). Tersusunnya rencana kerja di kanagarian berikutnya untuk menyelesaikan permasalahan dibidang ekonomi yang dihadapi masyarakat. Luaran : (1). Perbaikan sistim, peningkatan produksi dan pendapatan masyarakat, (2). Produk kerajinan lidi (alat rumah tangga, dan lain-lain)

Indikator Capaian. (1). Terjadi perbedaan pendapatan dan keuntungan kelompok masyarakat sebelum dan sesudah membuat kerajinan dari lidi kelapa, (2). Terjadi penambahan pengetahuan dan keterampilan masyarakat dalam membuat produk kerajinan, bisa menggunakan dan memasarkan sendiri. (3). Masyarakat mampu menganalisis sendiri usahanya

\subsection{Evaluasi Kegiatan}

Kriteri yang digunakan dalam mengevaluasi kegiatan pengabdian ini meliputi :

(1)Peran serta aktif peserta selama ceramah saat sesi penyuluhan, melalui aktivitas selama diskusi serta umpan balik dan absensi atau daftar hadir.

(2)Kemampuan peserta dalam praktek pembuatan kerajinan tangan berbahan lidi kelapa selama pelatihan berlangsung, dengan menunjukkan hasil/produk yang dihasilkan 1 orang 1 produk kerajinan piring 


\section{HASIL DAN PEMBAHASAN}

Kenagarian IV Koto Mudik Kecamatan Batang Kapas terdiri dari 3 Kampung yaitu Kampung Balai Lamo, Kampung Lubuk Bangka dan Kampung Palo Banda yang mempunyai luas tanah \pm 15.355 Ha yang terdiri dari luas pemukiman $\pm 433 \mathrm{Ha}$, Luas pertanian $\pm 782 \mathrm{Ha}$, Lahan tidur \pm 11.537 dan lahan lainnya $\pm 136,5$. Kenagarian IV Koto Mudik mempunyai jarak tempuh dari Kecamatan $6 \mathrm{Km}$ dengan lama jarak tempuh $1 / 4$ jam, sedangkan jarak dari Ibu Kota/ Kabupaten $22 \mathrm{Km}$ dengan lama jarak tempuh $1 \frac{1}{2}$ jam. Pada umumnya masyarakat IV Koto Mudik mata pencariannya bertani dan beternak yang sesuai dengan kondisi daerahnya yang mempunyai lahan yang luas. Diseputar kiri dan kanan jalan terlihat areal sawah yang membentang luas. Meskipun ada juga penduduk yang bermata pencarian lainnya.

Kegiatan penyuluhan dan pelatihan kerajinan lidi ini dimulai sejak dilakukan perekrutan terhadap 30 orang masyarakat. Masyarakat yang terlibat haruslah memenuhi kriteria yang sudah ditetapkan yaitu ibu-ibu rumah tangga petani serta bersedia mengikuti pelatihan dan mau mengikuti aturanaturan yang berlaku selama kegiatan pelatihan. Jumlah peserta kelompok masyarakat sebanyak 30 orang. Penyuluhan dan pelatihan pembuatan kerajinan lidi dilakukan bekerjasama dengan pengrajin pembuat lidi sekaligus akan menampung produk kerajinan yang akan dihasilkan oleh masyarakat.

Masyarakat memberikan respon yang positif dalam pelaksanaaan penyuluhan dan pelatihan yang diberikan. Hal ini dapat dilihat dari keterlibatannya dalam diskusi-diskusi dan pertanyaanpertanyaan yang diajukan kepada nara sumber. Materi-materi yang diberikan selama penyuluhan terus diterapkan dalam kegiatan praktek dalam pembuatan kerajinan lidi. Selanjutnya dari pihak Nagari juga menyambut sangat positif dan mereka berharap kegiatan ini terlaksana dengan baik dan Nagari IV Koto Mudik. Selanjutnya dari pihak Universitas Ekasakti lewat Dekan Fakultas Pertanian Universitas Ekasakti menyambut baik usulan ini. Langkat berikutnya dibuat semacam kerjasama untuk menjadikan kanagarian IV Koto Mudik dijadikan Desa Binaan oleh Universitas Ekasakti Padang khususnya dalam sektor pertanian dan industri kreatif. Industri kreatif yang ditangani adalah bidang pengolahan kelapa karena sebagaian besar (90\%) penduduknya mempunyai mata pencaharian utama adalah sebagai petani khususnya padi sawah.

Berdasarkan gambaran diatas terlihat bahwa peserta penyuluhan dan pelatihan dalam hal ini adalah masyarakat Nagari IV Koto Mudik sudah berbaur dengan baik dengan narasumber dan masyarakat menerima materi yang disampaikan narasumber dengan tangan terbuka dan mereka membuka peluang kepada staf pengajar yang lain untuk bisa mengabdikan ilmu yang telah didapat di kampus dan belajar juga kepada petani tentang berbagai hal yang ada pada petani. Kegiatan penyuluhan dan pelatihan diakhiri dengan saling berkenalan antara masyarakat dengancalon mitra pembeli. Dengan demikian diharapkan terjalan kerjasama yang baik setelah kegiatan pelatihan ini berlangsung.

Kendala-Kendala. (1). Dalam pengerjaan pembuatan produk kerajinan lidi masih belum maksimal. (2). Lidi yang digunakan dalam pembuatan kerajinan agar kualitasnya bisa ditingkatkan. (3). Dalam hal pembuatan kerajinan lidi semangat kelompok masyarakat belum optimal karena belum sampai tahap penjualan, (4). Harga kerajinan lidi kalau dijual masih murah.

Solusi yang ditawarkan. (1). Memfasilitasi pasar dalam penjualan produk kerajinan lidi agar mendapat harga yang wajar, (2). Perlu dilakukan pendampingan dalam merancang kerajinan lidi menjadi produk-produk yang diperlukan oleh pasar, (3). Mencoba untuk membantu kelompok masyarakat dengan memfasilitasi membuat proposal usulan permintaan fasilitas pendukung kepada pemerintah daerah..(4). Merancang bersama kelompok masyarakat untuk membuat produk kerajinan lidi yang dikemas dan diberi label. (5). Merencanakan kegiatan berikutnya dalam bentuk 
kerjasama antara masyarakat Nagari IV Koto Mudik dengan LPPM Universitas Ekasakti. Perencanaan jangka panjang yang akan dilakukan adalah menindaklanjuti kerjasama antara nagari dengan Perguruan Tinggi Universitas Ekasakti untuk menjadikan Nagari IV Koto Mudik bisa jadikan desa binaan Fakultas Pertanian Universitas Ekasakti dengan melibatkan dosen sehingga bisa melakukan pengabdian secara rutin kepada masyarakat yang difasilitasi pemda dan perguruan tinggi dan tindak lanjut program yang berhubungan dengan pengelolaan program, keterlibatan mitra dan masyarakat dilakukan pembagian tugas yang jelas agar pelaksanaan program bisa berjalan dengan lancar. Mitra membuat rencana tindak lanjut, yang diketahui oleh pemda setempat (nagari) dan disetujui oleh Dinas terkait

\section{SIMPULAN DAN SARAN}

1. Usaha pembuatan produk kerajinan dari lidi dapat meningkatkan pendapatan kelompok masyarakat peserta kegiatan.

2. Kelompok masyarakat sudah mempunyai pengetahuan dan keterampilan dalam membuat produk kerajinan dari lidi seperti piring makan, piring tempat buah.

3. Agar kelompok masyarakat terus berlanjut membuat produk kerajinan diperlukan adanya pendampingan dan memberikan contoh dilapangan secara langsung.

4. Untuk meningkatkan kemampuan manajemen masyarakat dalam membuat kerajinan lidi termasuk dalam mengelola hasil usahanya perlu dilakukan pelatihan pembukuan.

\section{UCAPAN TERIMA KASIH}

Terima kasih kami sampaikan kepada pihak-pihak yang telah membantu terselenggaranya kegiatan pengabdian masyarakat ini. Kepada Rektor Universitas Ekasakti, Ketua LPPM Universitas Ekasakti dan Dekan Fakultas Pertanian Universitas Ekasakti. . Kepada pembicara Dr. Ir.I Ketut Budaraga,MS dan Drs Syafrudin selaku pembicara dan mitra pemasaran, Ir.Gusriati,MSi dan Wawan Sumarno sebagai tim serta kepada Walinagari IV Koto Mudik serta seluruh peserta pengabdian masyarakat.

\section{DAFTAR PUSTAKA}

Anonim, 2016. Kecamatan Batang Kapas dalam Angka. Kanagarian IV Koto Mudik Kecamatan Batang Kapas Kabupaten Pesisir Selatan.

Wikipedia. 2015. Kelapa. Didapat dari: https://id.wikipedia.org/wiki/Kelapa.

Tuasikal M.Yamin, Jayadi MR., Afriandi Y., Belanosa, Hadi, Dewanti, Novitasasi, Pujiati, Rosida, Risky, Setiawan, Mawan, Nurkholis, Tamrin, Wirawan, Mahara dan Fadriaty, 2015. Penyuluhan dan Pelatihan Pengolahan Sabut Kelapa. Jurnal Inovasi dan Kewirausahaan, Volume 4 (2); 93-97. 